\section{Tatakelola Inovatif dalam Penanganan Masyarakat Rentan Perkotaan: Belajar dari Kewiralembagaan Yayasan Girlan Nusantara}

Oleh:

\section{Eka Zuni Lusi Astuti ${ }^{1}$}

\begin{abstract}
Abstrak
Keberadaan masyarakat rentan menjadi perhatian dalam pembangunan perkotaan. Program-program penanganan masyarakat rentan berbasis negara belum dapat mengatasi persoalan tersebut. Di sisi lain, aktor dari akar rumput turun tangan melalui berbagai institusi inovatif berbasis masyarakat. Yayasan Girlan Nusantara merupakan salah satu institusi inovatif yang berkiprah dalam penanganan masyarakat rentan di Yogyakarta. Menggunakan pendekatan institutional entrepreneurship (kewiralembagaan), penelitian ini bertujuan untuk mengelaborasi kiprah inovatif Yayasan Girlan Nusantara dalam penanganan masyarakat rentan. Penelitian ini menggunakan metode penelitian kualitatif dengan teknik pengumpulan data berupa observasi dan wawancara mendalam dan interpretasi data menggunakan metode kualitatif. Temuan dari penelitian ini bahwa aktor (wiralembagawan) dapat menentukan keberhasilan institusi inovatif. Tatakelola inovatif dapat berjalan efektif karena wiralembagawan memiliki modal sumber daya manusia, modal sosial, dan keterampilan sosial.
\end{abstract}

Kata kunci: kewiralembagaan, masyarakat rentan perkotaan, institusi inovatif

\footnotetext{
${ }^{1}$ Eka Zuni Lusi Astuti adalah staf pengajar pada Departemen Pembangunan Sosial dan Kesejahteraan, FISIPOL UGM.
}

\begin{abstract}
The presence of vulnerable communities is always a concern in urban development. However, state based programe of vulnerable communities cannot fully solve this issue. On the other hand, grass roots actors have attempted to intervene through various community based innovative institution. Yayasan Girlan Nusantara is one of innovative institution that manages to work with vulnerable communities problems in Yogyakarta. By emplying an institutional entrepreneurship approach, this studi aims to elaborate the innovative work of Yayasan Girlan Nusantara in treating vulnerable communities. This study employs a qualitative research method which includes data observation and indepth interviews and qualitative method of data intrepretation. The study shows that a founding actor (wiralembagawan) may determine a success of an innovative institution. Therefore the innovative governance works effectively due to the founding actors' human capital, social capital, and social skills.
\end{abstract}

Keywords: institutional entrepreneurship, vulnerable urban communities, innovative institution

\section{Pengantar}

Masyarakat perkotaan dihadapkan dengan berbagai persoalan. Salah satu persoalan sosial klasik yang dihadapi oleh masyarakat perkotaan adalah keberadaan masyarakat rentan. Mereka adalah masyarakat yang rentan secara ekonomi, sosial, maupun budaya. Selama ini, penanganan masyarakat rentan seolah-olah menjadi tanggung jawab negara semata. Kondisi ini ditegaskan oleh negara dalam pasal 5 Undang-Undang 
Jurnal Pemikiran Sosiologi Volume 4 No. 1, Januari 2017

Eka Zuni Lusi Astuti

Tata Kelola Inovatif dalam Penanganan Masyarakat Rentan Perkotaan: Belajar dari

Kewiralembagaan Yayasan Girlan Nusantara

Nomor 39 Tahun 1999, bahwa "setiap orang yang termasuk kelompok masyarakat yang rentan berhak memperoleh perlakuan dan perlindungan lebih berkenaan dengan kekhususannya". Namun demikian, program-program penanganan masyarakat rentan dari negara, baik berupa bantuan karitatif maupun pemberdayaan, dipandang belum bisa mengatasi persoalan yang dihadapi masyarakat rentan. Salah satu penyebabnya adalah rendahnya kapasitas untuk mengakses dan keterbatasan akses masyarakat rentan terhadap fasiltas dari negara. Ini tidak terlepas dari kompleksitas persoalan yang dihadapi oleh masyarakat rentan di perkotaan itu sendiri.

Demokrasi dan good governance dalam konteks penanganan masyarakat rentan, memaknai demokrasi sebagai demokrasi partisipatoris, yaitu terbukanya ruang partisipasi bagi negara, masyarakat sipil, dan korporasi dalam penanganan masyarakat rentan. Institusi inovatif yang berkiprah dalam penanganan masyarakat rentan muncul karena adanya demokrasi partisipatoris tersebut. Sementara itu, good governance dimaknai sebagai adanya innovative governance dalam pemberian layanan bagi masyarakat rentan yang dilakukan oleh institusi inovatif. Pergeseran model dan modus pelayanan lembaga sosial dari government ke governance yang berimplikasi pada bergesernya peran one significant actor menuju no one significant actor atau everyone significant actor.

Dalam kajian ini yang dimaksud dengan tatakelola inovatif adalah manajemen institusi inovatif dalam penangan masyarakat rentan. Bahwa penanganan masyarakat rentan tidak hanya didominasi oleh negara (one significant actor) karena juga telah dilakukan oleh masyarakat sipil dan korporasi yang berarti no one/everyone significant actor. Tatakelola inovatif oleh institusi inovatif dalam penanganan masyarakat rentan berbeda dengan yang dilakukan oleh negara. Tatakelola inovatif berfokus pada modal sosial yang dibangun secara bottom up. Berbeda dengan tatakelola dari negara yang birokratis, berbasis program sehingga bersifat top down.

Selain menjadi salah satu jawaban dalam upaya mengatasi persoalan yang dihadapi masyarakat rentan di perkotaan. Institusi inovatif ini juga memposisikan diri sebagai fasilitator program-program dari negara dalam mengatasi persoalan yang dihadapi oleh masyarakat rentan. Fakta tersebut merupakan bukti bahwa ada orang-orang yang tidak menerima begitu saja kondisi di hadapan mereka. Apabila dikaitkan dengan kajian kewiralembagaan, mereka dapat disebut sebagai wiralembagawan. Mereka tidak hanya menemukenali kontradiksi tetapi juga melakukan tindakan dan memunculkan inovasi institusi sebagai 
Jurnal Pemikiran Sosiologi Volume 4 No. 1, Januari 2017

Eka Zuni Lusi Astuti

Tata Kelola Inovatif dalam Penanganan Masyarakat Rentan Perkotaan: Belajar dari

Kewiralembagaan Yayasan Girlan Nusantara

produk dari kerja wiralembaga yang mereka lakukan. Tindakan-tindakan inovasi yang dimaksud seperti memberikan jaminan kesehatan bagi warga miskin atau memberikan pendidikan kepada anak jalanan secara nonformal. Inovasi institusi yang dilakukan wiralembagawan adalah produk dari kerja wiralembaga. Terdapat proses menemukenali kontradiksi, menghubungkan diri dengan eksternalitas melalui human capital, social capital, dan social skill, dan menentukan titik mula kegiatan sebelum akhirnya inovasi itu terjadi. Hal-hal inilah yang dikaji dalam tulisan ini.

Oleh karena itu, keterbatasan akses masyarakat rentan terhadap fasilitas negara membutuhkan institusi inovatif berbasis masyarakat yang mampu memenuhi kebutuhan masyarakat rentan. Pascareformasi, bermunculan berbagai institusi inovatif atas inisiasi masyarakat sipil yang mengangkat isu penanganan masyarakat rentan. Di Yogyakarta, institusi inovatif berkarakter sosial tumbuh subur. Salah satu institusi inovatif yang berkiprah dalam penanganan masyarakat rentan perkotaan di Yogyakarta adalah Yayasan Girlan Nusantara. Meskipun setiap individu di Yogyakarta hidup dalam setting sosial yang diwarnai dengan persoalan masyarakat rentan tersebut, tidak semua individu dapat menangkap gejala kontradiksi, yakni adanya kelambanan atau ketidakberhasilan negara dalam menangani mereka. Namun demikian, beberapa individu, salah satunya inisiator Yayasan Girlan Nusantara, termotivasi dan mampu melakukan aksi nyata dalam penanganan masyarakat rentan yakni dengan mendirikan organisasi sebagai wadah pelayanan.

Yayasan Girlan Nusantara menyediakan layanan rehabilitasi sosial bagi masyarakat rentan, seperti masyarakat miskin, anak jalanan, pekerja seks komersial (PSK), residivis serta pengidap HIV/AIDS. Yayasan Girlan Nusantara merupakan sebagian kecil lembaga yang lahir dari masyarakat, dijalankan oleh masyarakat, memiliki tatakelola yang tidak state-sentris, dan memiliki tujuan untuk kepentingan masyarakat. Proses kemunculan lembagalembaga tersebut tak lain dipengaruhi oleh adanya aktor/individu yang memiliki kemampuan sebagai wiralembagawan atau institutional entrepreneur. Maka dari itu, institusi berbasis masyarakat ini disebut sebagai institutional entrepreneurship yang merujuk pada kemampuan seseorang dalam membentuk institusi baru untuk tujuan sosial/politik (Pacheco, dkk. 2010). Tulisan ini akan mengelaborasi bagaimanakah inisiasi inovatif Yayasan Girlan Nusantara dan tata kelola inovatifnya dalam penanganan masyarakat rentan serta bagaimana peran wiralembagawan dalam 
Jurnal Pemikiran Sosiologi Volume 4 No. 1, Januari 2017

Eka Zuni Lusi Astuti

Tata Kelola Inovatif dalam Penanganan Masyarakat Rentan Perkotaan: Belajar dari

Kewiralembagaan Yayasan Girlan Nusantara

menemukan institusi inovatif dan

tatakelolanya.

\section{Metode Penelitian}

Tulisan ini disarikan dari hasil penelitian tentang tatakelola inovatif dalam penanganan masyarakat rentan serta peran wiralembagawan dalam mengembangkan institusi inovatif. Metode penelitian yang digunakan adalah kualitatif dengan pendekatan deskriptif. Creswell (1994) mengemukakan bahwa penelitian kualitatif adalah proses penyelidikan untuk memahami masalah sosial atau masalah manusia, berdasarkan pada penciptaan gambar holistik yang dibentuk kata-kata, melaporkan pandangan informan secara terperinci, dan disusun dalam sebuah latar ilmiah. Metode penelitian kualitatif digunakan untuk memahami inisiasi, tatakelola inovatif dan peran wiralembagawan di Yayasan Girlan Nusantara.

Lokasi penelitian di Ledoksari, Bokoharjo, Prambanan, Kabupaten Sleman di mana sekretariat Yayasan Girlan Nusantara berada, melakukan aktivitas penanganan masyarakat rentan serta di mana masyarakat rentan tinggal dan beraktivitas. Informan dalam penelitian ini adalah inisiator Yayasan Girlan Nusantara, binaan, masyarakat sekitar dan aktor di sekitarnya. Data-data dikumpulkan melalui observasi dan wawancara mendalam. Pengumpulan data di lapangan dilanjutkan dengan interpretasi data menggunakan pendekatan institutional entrepreneurship, triangulasi data dan penarikan kesimpulan. Melalui teknik ini, peneliti dapat mengetahui berbagai aktivitas wiralembagawan melalui institusi inovatif yang dikembangkannya dalam penanganan masyarakat rentan. Yayasan Girlan Nusantara memberikan pelayanan dan memberdayakan para penyandang masalah sosial melalui pendidikan serta peningkatan keterampilan. Hasil observasi dan wawancara mendalam diolah melalui reduksi data, diinterpretasikan, diperiksa keabsahannya melalui triangulasi data kemudian dianalisis dan disimpulkan.

\section{Institusi Inovatif dalam Institutional Entrepreneurship}

Pada umumnya entrepreneurship cenderung dikaitkan dengan terminologi ekonomi. Menurut Pacecho, et all (2010), bahwa kajian ekonomi (economic theory) maupun sosiologi (institutional theory) mengenal terminologi institutional entrepreneurship. Persamaan antara keduanya adalah menempatkan aktor sebagai inovator sekaligus agen perubahan. Menjadi berbeda karena institutional entrepreneur dalam ranah ekonomi bertujuan untuk menghasilkan keuntungan. Institutional entrepeneur dalam ranah teori insititusi bertujuan merumuskan 
Jurnal Pemikiran Sosiologi Volume 4 No. 1, Januari 2017

Eka Zuni Lusi Astuti

Tata Kelola Inovatif dalam Penanganan Masyarakat Rentan Perkotaan: Belajar dari

Kewiralembagaan Yayasan Girlan Nusantara

kesepakatan/institusi baru untuk tujuan sosial ataupun politik.

Struktur atau eksternalitas menjadi arena dalam kehidupan bermasyarakat. Pada umumnya masyarakat menerima eksternalitasnya begitu saja, jarang yang ingin merubahnya. Berbeda dengan seorang institutional entrepreneur atau yang dialihbahasakan oleh Kusworo (2015) menjadi wiralembagawan, mereka hidup dalam struktur tertentu dan berusaha untuk mengubah struktur tersebut atas suatu kepentingan. Wiralembagawan memiliki kemampuan mengidentifikasi persoalan dan mengubahnya menjadi lembaga baru. Tang (2010), setelah mempelajari bagaimana wirausahawan menemukan peluang bisnis di Cina. Ia menyimpulkan bahwa human capital, social capital dan social skill berhubungan dengan kemampuan mengenali peluang bisnis, turbulensi pribadi, dan persepsi mereka terhadap lingkungan. Kajian tersebut relevan untuk dihubungkan dengan pengembangan lembaga sosial. Menurut Kusworo (2015), bagaimanapun atribut pengambil resiko dan inovator yang disandang oleh wirausahawan juga mungkin ditemukan pada seorang wiralembagawan. Akan tetapi, kepemilikan atas ketiga hal tersebut tidak cukup. Seseorang dapat dikatakan sebagai wiralembagawan jika ia dapat memobilisasi struktur baru (Kusworo, 2015).
Kusworo (2015), bahwa aktor terhubung dengan struktur dalam ruang bernama Individual-Institutional Opportunity Nexus (IION). Terdapat dua entitas yang berbeda di dalam ruang tersebut, yaitu struktur dan aktor. Keduanya berkaitan dalam aspek tertentu. Masing-masing memiliki kemampuan untuk menginisiasi institusi inovatif. Walaupun demikian, aspek motivasi, institusi inovatif, dan outcome menjadi kepemilikan bersama. Aktor hidup dalam struktur sehingga dapat merubahnya. Upaya aktor merubah struktur menjadi suatu institusi inovatif inilah yang disebut sebagai entrepreneurship. Sementara itu, meskipun terletak pada entitas yang berbeda, aspek pengetahuan, relasi, diskursus, dan jaringan bekerja dengan saling mempengaruhi. Hubungan aspek-aspek tersebut dapat dilihat pada Bagan 1.

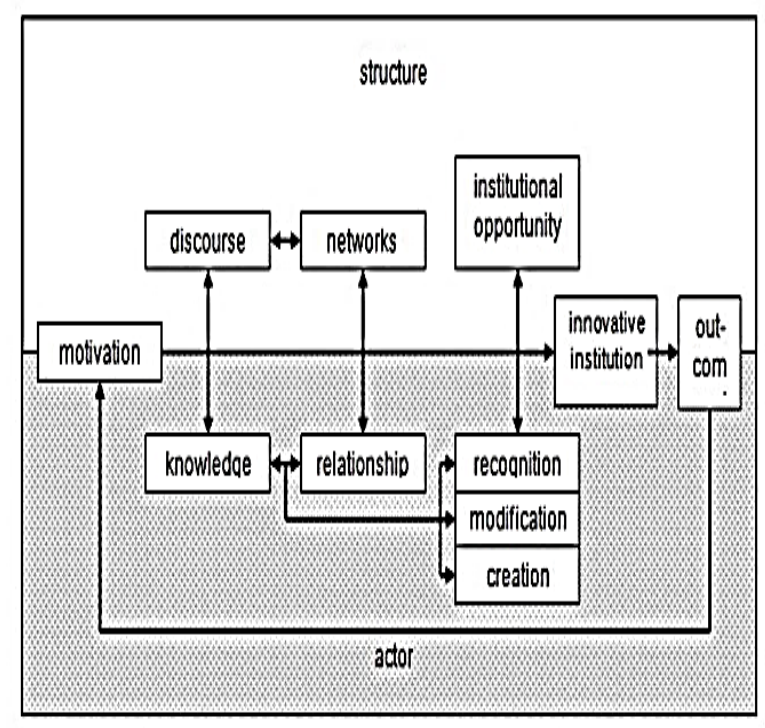

Bagan 1. Individual-Institutional Opportunity Nexus / IION (Sumber: Kusworo, 2015) 
Jurnal Pemikiran Sosiologi Volume 4 No. 1, Januari 2017

Eka Zuni Lusi Astuti

Tata Kelola Inovatif dalam Penanganan Masyarakat Rentan Perkotaan: Belajar dari

Kewiralembagaan Yayasan Girlan Nusantara

Bagan IION mengilusterasikan bahwa semua individu bersinggungan dengan eksternalitas. Akan tetapi hanya individu yang terhubung dengan struktur sehingga memiliki inisiatif membangun institusi inovatif. Supaya dapat terhubung dengan struktur, seorang individu harus memenuhi persyaratan, yakni hidup dalam eksternalitas, memiliki motivasi serta memiliki pengetahuan dan relasi. Sementara itu, institusi tidak dapat lepas dari 3 unsur penyusunnya, yaitu tujuan, formasi, dan fungsi. Ketika individu sudah terhubung dengan struktur, maka ia dapat menemukenali tujuan, formasi, dan fungsi. Kusworo (2015) memaparkannya dalam kuadran cartesian.

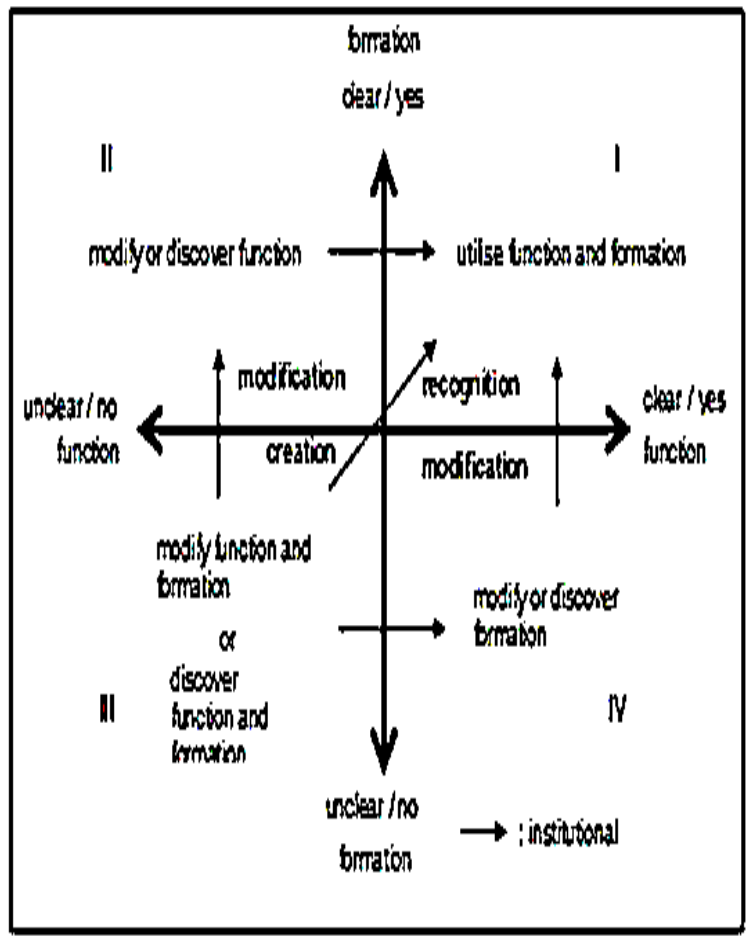

Bagan 2. Kuadran Cartesian Institutional Entrepreneurship (Sumber: Kusworo, 2015).
Pada kuadran I, formasi dan fungsi telah tersedia sehingga tugas wiralembagawan adalah menemukenali (recognizing) formasi dan fungsi supaya dapat mencapai tujuannya. Sebaliknya, pada kuadran III formasi dan fungsi belum ada dalam struktur. Disinilah wiralembagawan membuat (creating) formasi dan fungsi. Sementara itu, pada kuadran II dan kuadran IV salah satu formasi dan fungsi telah ditemukan. Wiralembagawan perlu melakukan modifikasi (modifying) supaya sesuai untuk membangun struktur baru.

\section{Analisis dan Pembahasan}

\section{Profil Yayasan Girlan Nusantara}

Yayasan Girlan Nusantara terletak di Jalan Prambanan-Piyungan Nomor 06 RT 04/07 Ledoksari, Bokoharjo, Prambanan, Sleman, DIY. Yayasan ini didirikan oleh Bapak Priyono, S.H., (Om Yon) pada tanggal 29 Juni 1993. Pada awalnya, Om Yon mendirikan Rumah Singgah Girlan Nusantara yang ditujukan sebagai tempat persinggahan atau tempat tinggal sementara bagi anak jalanan. Pada waktu itu banyak pengamen dari Surabaya, Sidoarjo dan Mojokerto yang datang untuk singgah. Anak-anak jalanan tersebut dibina dan diberdayakan supaya tidak kembali lagi ke jalan. Yayasan Girlan Nusantara juga menaungi dan membina pekerja seks komersial (PSK), pemulung, residivis, pengamen, anak putus sekolah, 
Jurnal Pemikiran Sosiologi Volume 4 No. 1, Januari 2017

Eka Zuni Lusi Astuti

Tata Kelola Inovatif dalam Penanganan Masyarakat Rentan Perkotaan: Belajar dari

Kewiralembagaan Yayasan Girlan Nusantara

korban narkoba, korban HIV/AIDS, korban

kekerasan dalam rumah tangga (KDRT), kaum dhuafa (miskin), dan kaum marginal lainnya yang berdomisili di bantaran Sungai Opak Prambanan dan sekitarnya.

Yayasan penanganan masyarakat rentan ini diberi nama Girlan Nusantara merujuk pada lokasi tempat dibangunnya. Girlan berarti "pinggir jalan". Nusantara memiliki makna bahwa binaan Girlan Nusantara berasal dari seluruh Indonesia. Dalam menjalankan upaya pengembangan institusionalnya, Yayasan Girlan Nusantara memiliki visi "bersama dengan masyarakat dan pemerintah bekerja sama dalam meningkatkan kesejahteraan di bidang sosial, kesehatan, dan pendidikan serta pengentasan kaum marginal". Visi tersebut diwujudkan melalui beberapa misi. Yaitu:

- Merubah pandangan masyarakat terhadap kaum marginal dari pandangan yang negatif (negative thinking) menjadi positif (positive thinking).

- Memberikan pendidikan kesetaraan dan keaksaraan atau kegiatan belajarmengajar dan pendidikan vokasional atau keterampilan sebagai penunjang kecakapan hidup.

- Meningkatkan sumber daya manusia kaum marginal melalui pemberdayaan.

- Membuka kerja sama dengan lembaga pemerintah dan lembaga lain dalam menangani masalah pendidikan, life skill, pemberdayaan, dan kesehatan.

- Memberikan pelayanan yang lebih baik meskipun sebagai anak jalanan, mereka merasa enjoy dan tidak terbebani dengan masalah yang sedang dihadapi oleh dirinya sendiri ataupun orang tuanya.

Visi dan misi tersebut dikembangkan untuk mencapai tujuan. Pertama, mengentaskan masyarakat dari kebodohan, kemiskinan, dan peningkatan kesehatan, sumber daya manusia serta pemberdayaan bagi masyarakat yang tertindas. Kedua, mendorong untuk meningkatkan kemandirian dan kesejahteraan kaum marginal. Ketiga, mengentaskan kehidupan kaum marginal. Keempat, rehabilitasi untuk anak jalanan, narkoba, HIV/AIDS, dan PSK dengan pelatihan dan keterampilan. Kelima, memberikan advokasi hukum terhadap hak-hak kaum marginal. Keenam, mengembalikan kaum marginal pada kehidupan masyarakat yang normatif.

Tata kelola inovatif dijabarkan melalui beberapa aspek, yakni eksternalitas, munculnya aktor, relasi aktor dengan struktur, kerja wiralembagawan (entrepreneurial task), dan kapasitas wiralembagawan. Aspek-aspek tersebut saling berkontribusi dalam proses mewujudkan institusi iovatif Yayasan Girlan Nusantara. 
Jurnal Pemikiran Sosiologi Volume 4 No. 1, Januari 2017

Eka Zuni Lusi Astuti

Tata Kelola Inovatif dalam Penanganan Masyarakat Rentan Perkotaan: Belajar dari

Kewiralembagaan Yayasan Girlan Nusantara

\section{Eksternalitas: Masalah Sosial Masyarakat Rentan Perkotaan}

Secara administratif, Desa Ledoksari dikategorikan sebagai desa. Akantetapi dilihat dari pola kehidupan masyarakat dan kondisi fisiknya, desa ini memiliki karakteristik masyarakat perkotaan. Persoalan sosial yang dihadapi sama kompleksnya dengan persoalan sosial di perkotaan. Wilayah ini sangat strategis bagi perputaran ekonomi. Pertama, dilalui oleh jalan lintas provinsi Jogja-Solo. Kedua, dekat dengan objek wisata Candi Prambanan. Kondisi ini menjadikan Ledoksari sebagai magnet bagi pendatang. Pendatang dari berbagai daerah datang ke Ledoksari untuk bertempat tinggal dan mengais rejeki di sepanjang Jalan Jogja-Solo atau di sekitar Candi Prambanan sebagai pedagang asongan dan pengamen.

Letak wilayahnya yang strategis menjadikan Ledoksari sebagai tempat persinggahan bagi anak jalanan, gelandangan, pelaku tindak kriminal, dan PSK (pekerja seksual komersial). Kondisi ini menjadikan wilayah ledoksari diwarnai berbagai masalah sosial seperti kemiskinan, adanya lokalisasi PSK, peredaran narkoba dan merebaknya virus HIV-AIDS. Kondisi ini dianggap oleh masyarakat sekitar sebagai masalah sosial. Menurut Parillo suatu situasi atau kondisi sosial dapat disebut sebagai masalah sosial apabila terdapat empat unsur yakni kondisi tersebut merupakan masalah yang bertahan untuk suatu periode waktu tertentu, dirasakan menyebabkan berbagai kerugian fisik atau nonfisik pada individu maupun masyarakat, merupakan pelanggaran terhadap nilai-nilai atau standar sosial dari salah satu atau beberapa sendi kehidupan masyarakat, dan menimbulkan kebutuhan akan pemecahan (Soetomo, 2010). Inilah eksternalitas yang dihadapi oleh warga Ledoksari. Keberadaan mereka sangat meresahkan warga sekitar. Pada umumnya warga memandang kondisi ini sebagai kondisi patologis sehingga berusaha menghindar supaya anak-anaknya tidak tertular perilaku menyimpang tersebut atau menutup mata dari persoalan yang ada.

\section{Munculnya Aktor}

Berbeda dengan warga pada umumnya yang melihat persoalan sosial di Ledoksari sebagai suatu aib sehingga harus dihindari, Bapak Priyono, S.H. atau dikenal dengan panggilan $\mathrm{Om}$ Yon memandang bahwa konidisi ini harus ditangani. Ia prihatin terhadap kondisi anak jalanan dan kaum rentan di sekitarnya. Om Yon berhasil menemukenali eksternalitas dan berusaha mengubahnya. Ia berpandangan bahwa masalah anak jalanan bisa diatasi dengan membina mereka melalui pendekatan khusus dan pendidikan. Sifat keras pada Om Yon mampu membangun kepercayaan 
Jurnal Pemikiran Sosiologi Volume 4 No. 1, Januari 2017

Eka Zuni Lusi Astuti

Tata Kelola Inovatif dalam Penanganan Masyarakat Rentan Perkotaan: Belajar dari

Kewiralembagaan Yayasan Girlan Nusantara

untuk merangkul maing-masing kelompok rentan.

Ia mengumpulkan anak-anak jalanan dan penyandang masalah sosial lainnya, menampung di rumahnya, dan membina mereka. Mereka direhabilitasi, diajak belajar berwirausaha, memberi fasilitasi modal, baik barang maupun uang, supaya dapat mandiri secara ekonomi. Di samping itu, Om Yon menanamkan nilai-nilai keagamaan untuk memperbaiki sisi spiritual mereka. Ia mengeluarkan uang pribadi untuk membiayai berbagai kegiatan binaannya. Ia rela menjual barang-barang pribadinya untuk mendirikan Yayasan Girlan Nusantara. Pendidikan menjadi fokus utama Om Yon untuk merehabilitasi binaannya. Ini sejalan dengan pendapat Jim Ife dan Frank Tesoriero (2006) bahwa Pendidikan adalah salah satu aspek terpenting dari peran seorang pekerja masyarakat, dan dengan begitu berbagai keterampilan dalam mendidik adalah sangat penting. Berbagai peran mendidik seorang pekerja masyarakat adalah peningkatan kesadaran, memberikan informasi, konfrontasi dan pelatihan.

\section{Relasi Aktor dengan Struktur}

Relasi aktor dan struktur merupakan suatu ruang dimana dimungkinkan munculnya institusi inovatif. Aktor merujuk pada seorang individu dengan semua atribut yang melekat pada dirinya. Sementara itu, struktur adalah eksternalitas yakni kondisi di luar individu yang direspon oleh aktor. Institusi inovatif dapat diproduksi ketika aktor dapat menemukenali tujuannya dan memanfaatkan peluang yang dihadirkan oleh eksternalitas. Om Yon menemukenali eksternalitas permasalahan sosial di sekitarnya yang kemudian menjadi motivasi didirikannya Yayasan Girlan Nusantara. Berikut bagan relasi aktor dengan struktur pada Yayasan Girlan Nusantara.

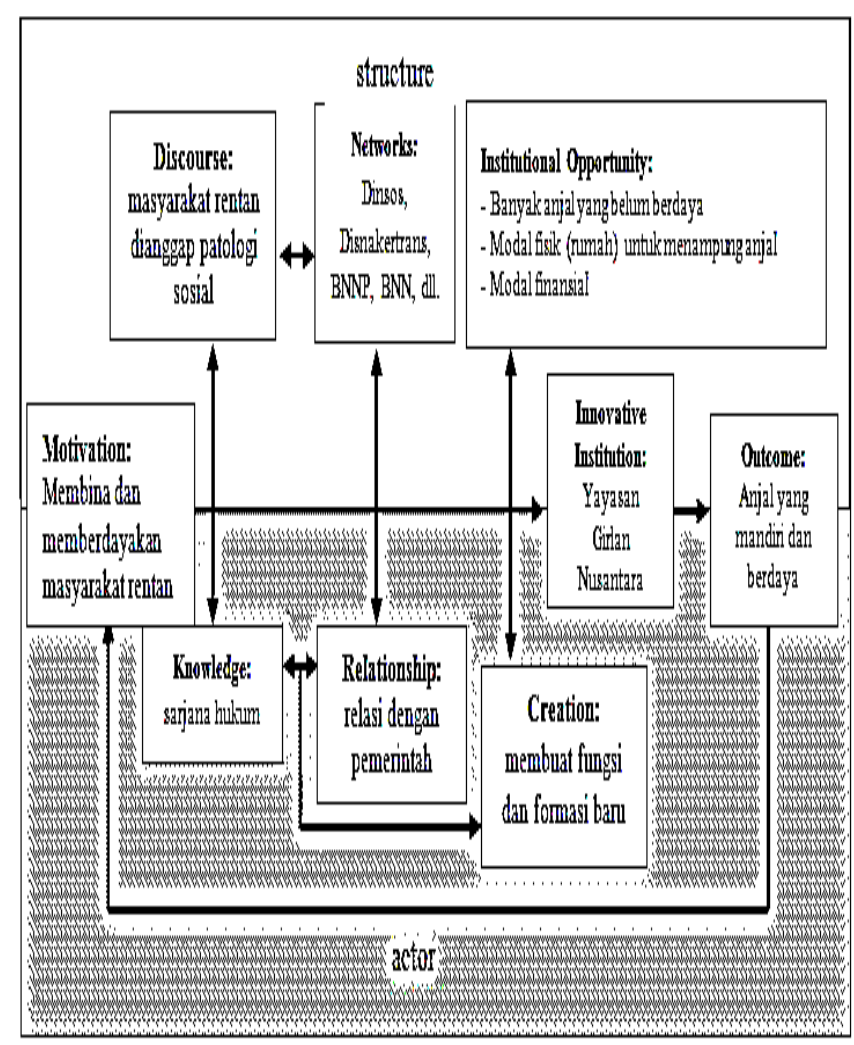

Bagan 3. Relasi Aktor-StrukturYayasan GIRLAN Nusantara (Sumber: interpretasi data menggunakan Bagan IION)

Bagan tersebut mengilusterasikan hubungan antara aktor dan struktur. Kondisi eksternal yang terjadi di dalam struktur adalah anggapan bahwa 
Jurnal Pemikiran Sosiologi Volume 4 No. 1, Januari 2017

Eka Zuni Lusi Astuti

Tata Kelola Inovatif dalam Penanganan Masyarakat Rentan Perkotaan: Belajar dari

Kewiralembagaan Yayasan Girlan Nusantara

penyandang masalah sosial adalah salah satu bentuk dari patologi sosial yang harus dihindari. Namun muncul anggapan lain bahwa mereka dibina dan direhabilitasi secara sosial. Hal ini mendorong aktor untuk mendirikan institusi baru Yayasan Girlan Nusantara bagi penanganan penyandang masalah sosial. Usaha ini didukung dengan adanya hubungan baik antara aktor dengan pemerintah sehingga penanganannya dapat berkelanjutan.

\section{Kerja Wiralembagawan}

Kerja wiralembagawan merupakan sebuah proses menentukan tujuan, formasi, dan fungsi. Karena merupakan institusi baru, kerja wiralembagawan (entrepreneurial task) pada Yayasan Girlan Nusantara merujuk pada proses inisiasi yayasan ini. Tahap menemukenali eksternalitas bermula dari keprihatinan aktor terhadap keberadaan masyarakat rentan di sekitarnya yang tidak mendapatkan perhatian, baik dari pemerintah maupun masyarakat. Aktor kemudian menyediakan rumahnya sebagai rumah singgah untuk anak jalanan. Tujuannya, pertama, membina anak jalanan supaya mandiri dan berdaya sehingga tidak kembali ke jalan dan kedua, mengembalikan perilaku anak jalanan sesuai norma dan nilai. Tidak hanya anak jalanan yang bisa mengakases rumah singgah. Semua orang yang membutuhkan keluarga dan mau menjalani rehabilitasi sosial diterima dengan baik di rumah singgah. Sejalan dengan pendapat Kartono (2007), bahwa kriminalitas bukan merupakan peristiwa herediter, bukan sebagai akibat perilaku bawaan sejak lahir maupun warisan biologis. Menurut Om Yon, perilaku menyimpang bisa diperbaiki melalui aktivitas belajar dan menanamkan kembali nilai dan norma yang ada di masyarakat.

Tahap selanjutnya adalah mengenali formasi dan fungsi. Dalam perkembangannya, jumlah anak jalanan yang singgah di rumah Om Yon semakin bertambah sehingga membutuhkan tempat yang lebih luas. Menghadapi ini, aktor mendirikan rumah singgah dan yayasan yang sah secara hukum untuk menjamin berfungsinya institusi. Selain itu, upaya legalisasi ini ditempuh supaya dapat meraih bantuan dari lembaga donor untuk pembiayaan berbagai program dan kegiataan rehabilitasi sosial. Proses inilah yang disebut mengenali formasi. Sedangkan proses mengenali fungsi berupa upaya aktor membentuk pengurus sukarela dan mencari volunteer untuk membantunya mengelola anak-anak binaan yang semakin bertambah. Dengan demikian, moment of institution pada kerja wiralembagawan yang terjadi adalah creation. 
Jurnal Pemikiran Sosiologi Volume 4 No. 1, Januari 2017

Eka Zuni Lusi Astuti

Tata Kelola Inovatif dalam Penanganan Masyarakat Rentan Perkotaan: Belajar dari

Kewiralembagaan Yayasan Girlan Nusantara

\section{Kapasitas Wiralembagawan}

Kapasitas aktor sebagai seorang wiralembagawan berhasil menciptakan tatakelola inovatif pada Yayasan Girlan Nusantara. Kapasitas wiralembagawan tersebut berupa modal sumber daya manusia (SDM), modal sosial, dan keterampilan sosial.

- Modal sumberdaya manusia

Modal sumber daya manusia merujuk pada pengetahuan dan latarbelakang aktor. Om Yon merupakan lulusan Fakultas Hukum, Universitas Gadjah Mada Yogyakarta. Pengetahuan ilmu hukum menjadi bekal untuk mengadvokasi anak-anak binaannya. Selain itu, aktor memiliki akumulasi pengetahuan dari keterlibatannya dalam forum komunikasi anti narkoba, GRANAT, dan tergabung dalam forum LSM DIY. Berbagai pengetahuan tersebut menjadi modal bagi pengembangan tatakelola inovatif pada Yayasan Girlan Nusantara.

- Modal sosial

Aktor dapat menjalin relasi dengan masyarakat sekitar, pemerintah dan NGO. Di Ledoksari, ia dikenal baik oleh warga karena sering bergaul dengan warga sekitar, meskipun ia merupakan warga pendatang. Pengalamannya berjualan buah di Pasar Prambanan menjadikannya dekat dengan warga. Ia berusaha melibatkan tokoh masyarakat lokal dan kader kesehatan dusun untuk bekerjasama melaksanakan berbagai kegiatan di Yayasan Girlan Nusantara.

- Keterampilan sosial

Keterampilan sosial yang dimiliki aktor berupa kemampuan membangun persepsi sosial, beradaptasi, mempengaruhi orang lain dan manajemen pengaruh/kesan. Sebelum adanya rumah singgah, Om Yon menampung anak-anak jalanan dan pengamen di rumahnya. Pembawaan yang keras pada diri Om Yon mampu "menjinakkan" anak-anak jalanan yang memiliki gaya hidup preman. Awalnya, Om Yon membiayai berbagai kegiatan untuk anak-anak binaannya menggunakan uangnya sendiri. Ia percaya bahwa merek bisa dibina dan direhabilitasi. Upaya tersebut sempat menuai penolakan dari warga, bahkan anak-anak binaannya diusir oleh warga. Meskipun demikian, Om Yon tetap melindungi dan membina anakanak binaannya. Ia berhasil meyakinkan masyarakat dengan adanya kegiatan positif yang dilakukan oleh anak-anak binaannya. Sampai saat ini Yayasan Girlan Nusantara mendapatkan respon positif dari masyarakat. Aktor berhasil melakukan manajemen pengaruh atau kesan masyarakat terhadap Yayasan Girlan Nusantara beserta binaannya. 
Jurnal Pemikiran Sosiologi Volume 4 No. 1, Januari 2017

Eka Zuni Lusi Astuti

Tata Kelola Inovatif dalam Penanganan Masyarakat Rentan Perkotaan: Belajar dari

Kewiralembagaan Yayasan Girlan Nusantara

Disamping itu, Yayasan Girlan

Nusantara juga menjalin kerjasama penanganan masyarakat rentan dengan berbagai instansi pemerintah, pihak swasta, NGO, dan akademisi.

\section{Peran Yayasan Girlan Nusantara dalam Penanganan Masyarakat Rentan Perkotaan}

Yayasan Girlan Nusantara berfokus pada penanganan kelompok penyandang masalah sosial yang mengalami penolakan dari lingkungannya atau sengaja melarikan diri dari lingkungannya karena tidak bisa menanggung stigma yang diberikan masyarakat dari mana mereka berasal. Mereka adalah anak jalanan, mantan pengguna narkoba, residivis, PSK, dan anak dari kelompok marginal lainnya. Anak-anak jalanan dibina supaya tidak lagi turun ke jalan. Pembinaan dilakukan dengan cara meningkatkan kapasitas anak-anak binaan supaya bisa mandiri, terutama secara ekonomi.

Penanganan masyarakat rentan dilakukan dengan beberapa model karena latar belakang masalah yang beragam. Upaya penanganan masyarakat rentan oleh Yayasan Girlan Nusantara dilakukan melalui sepuluh unit kerja yang dapat diklasifikasikan kedalam bidang pendidikan, kesehatan, keagamaan, advokasi, konseling, dan rehabilitasi.
Masing-masing unit kerja mempunyai mekanisme tersendiri dalam menjalankan tugasnya. Ada yang menggunakan pola pemberdayaan maupun kearah charity. Berikut sepuluh unit kerja tersebut.

\begin{tabular}{|c|c|c|}
\hline Bidang & Unit Kerja & $\begin{array}{l}\text { Metode } \\
\text { Penanganan }\end{array}$ \\
\hline \multirow[t]{5}{*}{ Pendidikan } & $\begin{array}{l}\text { 1. Rumah Singgah } \\
\text { (RS) }\end{array}$ & Charity \\
\hline & $\begin{array}{ll}\text { 2. } & \text { Sekolah } \\
& \text { Pendidikan } \\
& \text { Layanan Khusus } \\
& \text { (SPLK) }\end{array}$ & Pemberdayaan \\
\hline & $\begin{array}{l}\text { 3. } \\
\text { Busat Kegiatan } \\
\text { Belajar } \\
\text { Masyarakat } \\
\text { (PKBM) }\end{array}$ & Pemberdayaan \\
\hline & $\begin{array}{ll}\text { 4. } & \text { Taman Bacaan } \\
& \text { Masyarakat } \\
& \text { "Pustaka Girlan” }\end{array}$ & Charity \\
\hline & $\begin{array}{l}\text { 5. Pendidikan dan } \\
\text { Pemberdayaan } \\
\text { Perempuan } \\
\text { (PPP) }\end{array}$ & Pemberdayaan \\
\hline Kesehatan & $\begin{array}{l}\text { Pusat Layanan } \\
\text { Kesehatan Kaum } \\
\text { Marginal }\end{array}$ & Charity \\
\hline Keagamaan & $\begin{array}{l}\text { Pondok Pesantren } \\
\text { "Farid Al Girlani" } \\
\text { Berupa Diniyah } \\
\text { untuk anak jalanan } \\
\text { dan anak marginal }\end{array}$ & Pemberdayaan \\
\hline Advokasi & $\begin{array}{l}\text { Advokasi di bidang } \\
\text { hukum, pendidikan, } \\
\text { kesehatan, } \\
\text { perkawinan, adopsi, } \\
\text { dan kebijakan publik }\end{array}$ & Charity \\
\hline Konseling & $\begin{array}{l}\text { Trauma Center } \\
\text { Konseling untuk } \\
\text { kasus-kasus } \\
\text { kekerasan anak dan } \\
\text { perempuan; korban }\end{array}$ & Pemberdayaan \\
\hline
\end{tabular}


Jurnal Pemikiran Sosiologi Volume 4 No. 1, Januari 2017

Eka Zuni Lusi Astuti

Tata Kelola Inovatif dalam Penanganan Masyarakat Rentan Perkotaan: Belajar dari

Kewiralembagaan Yayasan Girlan Nusantara

\begin{tabular}{|c|c|c|}
\hline & $\begin{array}{l}\text { bencana dan konflik } \\
\text { sosial; korban } \\
\text { narkotika; korban } \\
\text { perdagangan } \\
\text { manusia (trafficking), } \\
\text { dan difabel }\end{array}$ & \\
\hline Rehabilitasi & $\begin{array}{l}\text { Rehabilitasi } \\
\text { pengguna Narkoba, } \\
\text { penderita HIV/AIDS. } \\
\text { Residivis, dan PSK }\end{array}$ & Pemberdayaan \\
\hline
\end{tabular}

Tabel 1. Unit Kerja Yayasan Girlan Nusantara (Sumber: diolah dari data primer dan data sekunder hasil penelitian)

Unit kerja di bidang pendidikan meliputi RS (Rumah Singgah), SPLK (Sekolah Pendidikan Layanan Khusus), PKBM (Pusat Kegiatan Belajar Masyarakat), RBAJ (Rumah Belajar Anak Jalanan) dan TBM (Taman Belajar Masyarakat). Rumah Singgah merupakan tempat tinggal sementara atau sebagai tempat persinggahan anak jalanan. Tujuan didirikannya rumah singgah tersebut adalah untuk menciptakan rasa aman bagi anak jalanan sekaligus membangun kehidupan kekeluargaan bagi mereka. Di bidang pendidikan, Yayasan Girlan Nusantara memfasilitasi anak jalanan, anak putus sekolah, anak pelacur, anak pengamen, anak residivis, anak pemulung, dan anak-anak kaum marginal melalui SPLK. SPLK memberikan pembelajaran non formal, pendidikan keterampilan, pendidikan seni tari, pendidikan seni musik, pendidikan beladiri, IT (komputer dan internet), dan beasiswa.
Fasilitasi pendidikan dilakukan melalui PKBM dan RBAJ. Keduanya digunakan untuk menyelenggarakan pendidikan kesetaraan dan keaksaraan. PKBM dan RBAJ juga memfasilitasi program Kejar Paket A, B dan C, Keaksaraan Fungsional bagi Komunitas Khusus, Dasar, Lanjutan, dan Mandiri serta KWD (Kursus Wirausaha Desa). Akses terhadap buku-buku dilakukan melalui TBM Girlan Pustaka, yaitu sarana pendidikan melalui perpustakaan terpadu. Sementara itu, untuk menciptakan kehidupan spriritualitas anak-anak penyandang masalah sosial, dilakukan melalui Pontren "Farid Al Girlani". Sebuah pondok pesantren diniyyah yang dikhususkan untuk anak jalanan dan anak marjinal. Pondok pesantren ini bertujuan untuk menanamkan kembali nilai-nilai agama supaya dapat mendorong perubahan perilaku mereka menjadi lebih santun.

Pelayanan kesehatan diselenggarakan melalui PLKK (Pusat Kegiatan Layanan Kaum Marginal). Unit ini memberikan layanan kesehatan melalui jaminan kesehatan sosial kelompok. Layanan kesehatan ini berfokus pada pemeriksaan rutin untuk mencegah penyebaran penyakit HIV/AIDS pada PSK, pecandu narkoba, dan kelompok marginal lainnya. Sementara itu, di bidang rehabilitasi terdapat Pusat Rehabilitasi Girlan Nusantara untuk korban narkoba dan HIV/AIDS, residivis, dan PSK. Penanganan korban KDRT, TKW, 
Jurnal Pemikiran Sosiologi Volume 4 No. 1, Januari 2017

Eka Zuni Lusi Astuti

Tata Kelola Inovatif dalam Penanganan Masyarakat Rentan Perkotaan: Belajar dari

Kewiralembagaan Yayasan Girlan Nusantara

masyarakat marginal dan difabel serta trafficking dilakukan melalui PPP (Pendidikan dan Pemberdayaan Perempuan). Kegiatannya berupa pelatihan dan pemberdayaan. Unit advokasi berfungsi untuk memberikan bantuan advokasi di bidang hukum, pendidikan, perkawinan, adopsi, kesehatan, dan kebijakan publik. Unit Trauma Center berfungsi untuk memberikan pendampingan terhadap korban kekerasan anak dan perempuan termasuk KDRT, korban bencana alam, konflik sosial, korban NAPZA, human trafficking, masyarakat marjinal dan difabel melalui konseling, pelatihan, dan pemberdayaan.

Dari sepuluh unit kerja yang ada, empat unit kerja memberikan pelayanan berupa charity yang diberikan secara cuma-cuma untuk segera menangani masalah yang dihadapi. Empat unit yang dimaksud ialah Rumah Singgah, Taman Bacaan Masyarakat "Pustaka Girlan", Pusat Layanan Kesehatan Kaum Marginal. Sementara itu, enam unit kerja menggunakan menggunakan metode pemberdayaan. Unit-unit tersebut adalah Sekolah Pendidikan Layanan Khusus, Pusat Kegiatan Belajar Masyarakat, Pendidikan dan Pemberdayaan Perempuan, Pondok Pesantren "Farid Al Girlani", Advokasi, Trauma Center, dan Rehabilitasi pengguna Narkoba, penderita HIV/AIDS, residivis, dan PSK. Upaya pemberdayaan bertujuan untuk memberdayakan dan meningkatkan kapasitas kaum marginal sehingga mampu untuk hidup mandiri.

Yayasan Girlan Nusantara juga menjalin melakukan penanganan masyarakat rentan dengan berbagai instansi pemerintah, pihak swasta, NGO, dan akademisi. Sejak tahun 2000, Yayasan Girlan Nusantara bekerjasama melakukan berbagai pelatihan dengan Disnakertrans Kabupaten Sleman, Dinsos Kabupaten Sleman, Disdik Kabupaten Sleman, Dinsos DIY, Disdik DIY dan berbagai instansi pemerintah lainnya, baik di tingkat kabupaten maupun provinsi. Berikut berbagai kegiatan pemberdayaan masyarakat rentan kerjasama Yayasan Girlan Nusantara dengan pemerintah, sektor swasta, NGO, dan akademisi.

\begin{tabular}{|c|c|c|}
\hline \multicolumn{2}{|c|}{ Pemberi Bantuan } & \multirow{2}{*}{$\begin{array}{l}\text { Bentuk } \\
\text { Bantuan/Kegiatan }\end{array}$} \\
\hline Aktor & $\begin{array}{l}\text { Nama } \\
\text { Lembaga }\end{array}$ & \\
\hline \multirow[t]{3}{*}{ Negara } & $\begin{array}{l}\text { Disnakertrans } \\
\text { Kabupaten } \\
\text { Sleman }\end{array}$ & \begin{tabular}{|l} 
1. \\
Pelatihan Otomotif \\
dan Perbengkelan \\
$(2000-2006)$ \\
Pelatihan Menjahit \\
Dasar dan Lanjutan \\
(2003) \\
Pelatihan Tata Rias \\
dan Adi Busana \\
(2004)
\end{tabular} \\
\hline & $\begin{array}{l}\text { Dinsos } \\
\text { Kabupaten } \\
\text { Sleman }\end{array}$ & 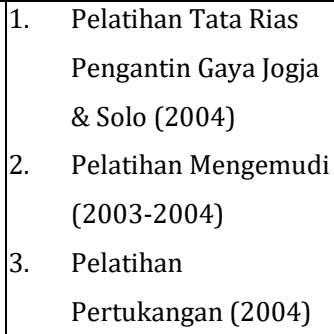 \\
\hline & \begin{tabular}{|l} 
Disdik \\
Kabupaten \\
Sleman
\end{tabular} & Kejar Paket C (2010) \\
\hline
\end{tabular}


Jurnal Pemikiran Sosiologi Volume 4 No. 1, Januari 2017

Eka Zuni Lusi Astuti

Tata Kelola Inovatif dalam Penanganan Masyarakat Rentan Perkotaan: Belajar dari Kewiralembagaan Yayasan Girlan Nusantara

\begin{tabular}{|c|c|}
\hline Dinsos DIY & \begin{tabular}{|ll} 
1. & Pelatihan Membuat \\
& Aquarium (1999- \\
& $2001)$ \\
2. & Pelatihan Sablon \\
& $(2001,2006,2009)$ \\
3. & Pelatihan Otomotif \\
& $(2002,2003,2006$, \\
& $2008)$ \\
4. & Pemberdayaan Anak \\
& Jalanan melalui \\
& Ternak Domba (2011)
\end{tabular} \\
\hline $\begin{array}{l}\text { Dinas } \\
\text { Pendidikan } \\
\text { DIY }\end{array}$ & \begin{tabular}{|ll} 
1. & Rumah Belajar Anak \\
& Jalanan (2000) \\
2. & Taman Bacaan \\
& Masyarakat/ \\
& Perpustakaan (2007) \\
3. & Pelatihan Budidaya \\
& Tanaman Hias (2007) \\
4. & Kejar Paket B dan C \\
& (2000-2009) \\
5. & Keaksaraan \\
& Fungsional Dasar dan \\
& Lanjutan (2005-2009) \\
6. & Pelatihan Membatik \\
(2009) & Sekolah Pendidikan \\
Layanan Khusus \\
(SPLK) (2009-2010)
\end{tabular} \\
\hline $\begin{array}{l}\text { Disdikpora } \\
\text { DIY }\end{array}$ & \begin{tabular}{|ll} 
1. & Kejar Paket B Kelas \\
& VIII (2010) \\
2. & Kejar Paket B lanjutan \\
& II/Kelas IX \\
3. & Program \\
& Pemdampingan Anak \\
& Jalanan melalui \\
& Pendidikan \\
& Perlindungan Anak \\
& Jalanan (2011) \\
4. & Program \\
& Pembelajaran \\
& Kecakapan Hidup \\
& Pemberdayaan \\
& Perempuan (2011)
\end{tabular} \\
\hline DPPKA DIY & $\begin{array}{l}\text { Pelatihan Komputer dan } \\
\text { Internet (2010) }\end{array}$ \\
\hline Pemprov DIY & $\begin{array}{l}\text { Pelatihan Pembuatan Kue } \\
\text { Kering dan Kue Basah }\end{array}$ \\
\hline
\end{tabular}

\begin{tabular}{|c|c|c|}
\hline & & \begin{tabular}{|l|} 
untuk Perempuan \\
Bantaran Kali Opak \\
Prambanan (2008-2009)
\end{tabular} \\
\hline & $\begin{array}{l}\text { Kemenag } \\
\text { Kanwil DIY }\end{array}$ & \begin{tabular}{|ll}
1. & Pondok Pesantren \\
& Anak Jalanan dan \\
& Anak Marjinal (2010- \\
& 2011) \\
2. & Pontren Anak Jalanan \\
& dan Anak Marjinal \\
& Lanjutan
\end{tabular} \\
\hline & $\begin{array}{l}\text { Kementerian } \\
\text { Sosial RI }\end{array}$ & \begin{tabular}{|ll} 
1. & Program 100 Hari \\
2. & $\begin{array}{l}\text { Menteri Sosial (2009) } \\
(2009-2010)\end{array}$ \\
3. & Pelatihan Mengemudi \\
& $(2009-2010)$ \\
4. & Pelatihan Memasak \\
& $(2009-2010)$ \\
5. & Pelatihan Budidaya \\
& Ikan Air Tawar (2009- \\
& 2010) \\
6. & Program Bimbingan \\
& Sosial dan \\
& Ketrampilan Program \\
& "DESAKU MENANTI I" \\
(2015)
\end{tabular} \\
\hline & BNN & $\begin{array}{l}\text { Kunjungan dari BNN } \\
(2015)\end{array}$ \\
\hline & BNPB DIY & Jogja Gumregah (2015) \\
\hline & $\begin{array}{l}\text { BLKPP } \\
\text { Yogyakarta }\end{array}$ & Pelatihan Tata Boga \\
\hline NGO & $\begin{array}{l}\text { Royal Silk } \\
\text { Foundation }\end{array}$ & $\begin{array}{l}\text { Pelatihan Kain Perca } \\
(2011)\end{array}$ \\
\hline & Joglo Tani & $\begin{array}{l}\text { Pelatihan Pertanian } \\
(2015)\end{array}$ \\
\hline & ACICIS & $\begin{array}{l}\text { Pelatihan Kerajinan Fiber } \\
\text { Glass dan Kristik (2004) }\end{array}$ \\
\hline Swasta & PT. Telkom & $\begin{array}{l}\text { Pernikahan Massal (2006- } \\
\text { 2007) }\end{array}$ \\
\hline & ADB & $\begin{array}{l}\text { Pelatihan Membuat } \\
\text { Makanan Kecil Tradisional } \\
(2001-2002)\end{array}$ \\
\hline & CSR & \begin{tabular}{|l} 
Pelatihan Service HP Anak \\
\end{tabular} \\
\hline
\end{tabular}


Jurnal Pemikiran Sosiologi Volume 4 No. 1, Januari 2017

Eka Zuni Lusi Astuti

Tata Kelola Inovatif dalam Penanganan Masyarakat Rentan Perkotaan: Belajar dari

Kewiralembagaan Yayasan Girlan Nusantara

\begin{tabular}{|l|l|l|}
\hline & $\begin{array}{l}\text { Telkomsel-Ma } \\
\text { Cell }\end{array}$ & Jalanan dan Difabel (2010) \\
\hline Akademisi & $\begin{array}{l}\text { STUBE } \\
\text { Yogyakarta }\end{array}$ & $\begin{array}{l}\text { Pelatihan Kerajinan Daur } \\
\text { Ulang (2009) }\end{array}$ \\
\cline { 2 - 3 } & FISIPOL UGM & $\begin{array}{l}\text { Kunjungan KAPSTRA PSdK } \\
\text { FISIPOL UGM (2012) }\end{array}$ \\
\hline
\end{tabular}

Tabel 2. Kegiatan Yayasan Girlan Nusantara (Sumber: diolah dari data primer dan data sekunder hasil penelitian)

Yayasan Girlan Nusantara juga turut andil dalam pemberdayaan masyarakat rentan di sekitarnya. Sasarannya adalah masyarakat yang rentan secara ekonomi. Yayasan ini juga berperan sebagai fasilitator program yang didukung dari berbagai instansi, seperti pelatihan dan bantuan modal untuk usaha masyarakat miskin. Keberadaan yayasan ini membantu pemerintah dalam menjalankan program-program penanganan masyarakat rentan.

\section{Kesimpulan}

Pasca reformasi, perkembangan institusi inovatif di berbagai daerah di Indonesia bagaikan cendawan di musim hujan. Demikian halnya dengan institusi inovatif Yayasan Girlan Nusantara terbukti dapat membantu negara untuk mengatasi persoalan-persoalan yang dihadapi oleh masyarakat rentan perkotaan, seperti anak jalanan dan individu-individu penyandang masalah sosial. Penelitian terhadap institusi inovatif Yayasan Girlan Nusantara dalam penanganan masyarakat rentan perkotaan menghasilkan beberapa kesimpulan terhadap upaya tata kelola inovatif. Pertama, tata kelola inovatif hanya dapat dilakukan oleh seorang wiralembagawan yang memiliki karakteristik berupa pengetahuan (knowledge), keterampilan sosial (social skill), kemampuan menghadapi kejadian yang tidak terduga dan modal. Modal yang dimaksud dapat berupa materi maupun jejaring yang dapat digunakan untuk mengembangkan institusi inovatif.

Kedua, keberhasilan tata kelola inovatif sangat ditentukan oleh dukungan dari pihak ketiga, yaitu pemerintah dan lembaga donor. Dukungan dari pihak ketiga ini sangat berpengaruh terhadap dinamika kegiatan dan keberlanjutan institusi inovatif. Secara tidak langsung, pihak ketiga yang memberikan dukungan terhadap institusi inovatif memberikan motivasi supaya institusi dampingannya menjadi lebih. Pihak ketiga tidak akan mau menjalin kerjasama dengan institusi yang tidak berkompeten. Yayasan Girlan Nusantara, terbukti memiliki jejaring yang baik dan semakin berkembang.

Ketiga, promosi dapat mendorong berkembang dan berkelanjutannya institusi inovatif. Seorang wiralembagawan yang menjadi penentu utama berjalannya tata kelola inovatif pasti memiliki kapasitas untuk melakukan promosi. Yayasan Girlan Nusantara melakukan promosi melalui 
Jurnal Pemikiran Sosiologi Volume 4 No. 1, Januari 2017

Eka Zuni Lusi Astuti

Tata Kelola Inovatif dalam Penanganan Masyarakat Rentan Perkotaan: Belajar dari

Kewiralembagaan Yayasan Girlan Nusantara

keikutsertaan, pada berbagai pelatihan dan seminar. yang diselenggarakan oleh pemerintah, swasta maupun NGO.

Berdasarkan hasil penelitian ini, direkomendasikan saran bagi pemerintah, masyarakat, organisasi masyarakat sipil (NGO), dan sektor swasta supaya dapat turut mengembangkan institusi inovatif, terutama yang berkecimpung dalam penanganan masyarakat rentan di perkotaan.

Bagi Pemerintah; pemerintah dapat memfasilitasi institusi inovatif melalui dukungan dana, kegiatan pendampingan, monitorong dan evaluasi serta membuat kebijakan yang bersifat bottom up supaya dapat mendukung pengembangan institusi inovatif.

Bagi Sektor Swasta:sektor swasta atau perusahaan dapat memasukkan kegiatan pemberdayaan institusi inovatif melalui Program Corporate Social Responsibility (CSR).

Bagi Organisasi Masyarakat Sipil (LSM/NGO): organisasi masyarakat sipil dapat melakukan advokasi kebijakan supaya pemangku kepentingan lebih ramah dan mau menyediakan akses terhadap berkembangnya institusi inovatif beserta ide-ide yang diusung.

Bagi Masyarakat: masyarakat diharapkan dapat berpartisipasi dalam kegiatan maupun layanan yang dilakukan oleh institusi inovatif dan turut serta mereplikasi dan mengembangkan institusi inovatif serupa.

Sinergisitas dari pemerintah, sektor swasta, organisasi masyarakat sipil dan masyarakat diharapkan dapat mendukung pengembangan institusi inovatif dalam penanganan masyarakat rentan perkotaan. Kedepan, diharapkan institusi inovatif dapat berkembang semakin banyak dan bebas mengekspresikan ide-ide dan kegiatannya di dalam penanganan masyarakat rentan perkotaan di Indonesia.

\section{Daftar Pustaka}

Creswell, John W.2010. Research Design Pendekatan Kualitatif, Kuantitatif, dan Mixed, Yogyakarta: Pustaka Pelajar.

Ife, Jim dan Frank Tesoriero. 2006. Community Development: Alternatif Pengembangan Masyarakat di Era Globalisasi. Yogyakarta: Pustaka Pelajar.

Kartono, Kartini. 2007. Patologi Sosial Jilid 1. Jakarta: PT RajaGrafindo Persada.

Kusworo, Hendrie Adji. 2015. Framing Poverty. An Institutional Entrepreneurship Approach On Poverty Alleviation Through Tourism. Doctoral thesis. Groningen: Rijksuniversiteit Groningen.

Pacheco, Desiree F., Jeffrey G. York, Thomas J. Dean, dan Saras D. Sarasvathy. 
Jurnal Pemikiran Sosiologi Volume 4 No. 1, Januari 2017

Eka Zuni Lusi Astuti

Tata Kelola Inovatif dalam Penanganan Masyarakat Rentan Perkotaan: Belajar dari Kewiralembagaan Yayasan Girlan Nusantara

2010. "The Coevolution of

Institutional Entrepreneurship: A

Tale of Two Theories." Journal of

Management.

Soetomo. 2010. Masalah Sosial dan Upaya

Pemecahannya. Yogyakarta: Pustaka Pelajar.

Tang, Jintong. 2010."How Entrepreneurs

Discover Opportunities in China: An

Institutional View." Asia Pasific

Journal of Management 461-469.

Sumber Lain:

Undang-Undang Nomor 39 Tahun 1999

tentang Hak Asasi Manusia. 